\title{
Nipple Neoplasm
}

National Cancer Institute

\section{Source}

National Cancer Institute. Nipple Neoplasm. NCI Thesaurus. Code C5212.

A benign or malignant neoplasm that arises in the area of the nipple. 